\title{
Suplementasi Enzim Papain Dalam Pakan Terhadap Performa Pertumbuhan, Efisiensi Pemanfaatan Pakan dan Kelulushidupan Udang Vaname (Litopenaeus vannamei)
}

\author{
Diana Rachmawati ${ }^{1 *}$, Johannes Hutabarat ${ }^{1}$, Eko Nurcahya Dewi ${ }^{2}$, Seto Windarto ${ }^{1}$ \\ ${ }^{1}$ Departemen Akuakultur, Fakultas Perikanan dan IImu Kelautan, Universitas Diponegoro \\ JI. Prof. H. Soedarto S.H, Tembalang, Semarang, Jawa Tengah 50275 Indonesia \\ ${ }^{2}$ Departemen Teknologi Hasil Perikanan Fakultas Perikanan dan IImu Kelautan, \\ Universitas Diponegoro \\ JI. Prof. H. Soedarto S.H, Tembalang, Semarang, Jawa Tengah 50275 Indonesia \\ *Corresponding author, e-mail: dianarachmawati1964@gmail.com
}

\begin{abstract}
ABSTRAK: Udang vaname (Litopenaeus vannamei) adalah karnivora yang sukar mencerna protein nabati dalam pakan sehingga efisiensi pemanfaatan pakan belum maksimal. Hampir 40$60 \%$ dari total biaya produksi hanya untuk biaya pakan. Efisiensi pemanfaatan pakan dapat ditingkatkan dengan penambahan enzim papain dalam pakan yang mampu meningkatkan penguraian dan pencernaan bahan pakan yang mengandung protein nabati sederhana sehingga dapat meningkatkan daya cerna protein pakan. Penelitian ini bertujuan mengkaji pengaruh suplementasi enzim papain dalam pakan terhadap efisiensi pemanfaatan pakan, performa pertumbuhan dan kelulushidupan udang vaname. Hewan uji berupa udang vaname dengan bobot rata-rata 3,02 $\pm 0,21 \mathrm{~g} /$ ekor yang diperoleh dari pembudidaya udang vaname Desa Blebak, Kecamatan Mlonggo, Jepara. Metode dalam penelitian ini adalah metode eksperimen, dengan Rancangan Acak Lengkap, 4 Perlakuan dan 3 kali pengulangan. Terdapat 4 perlakuan suplementasi enzim papain dalam pakan yaitu A (0\%), B $(0,1 \%), C(0,2 \%)$, dan D $(0,3 \%)$. Parameter yang diamati meliputi EPP, PER, RGR, SR dan parameter kualitas air. Hasil penelitian menunjukkan bahwa penambahan enzim papain dalam pakan meningkatkan EPP, PER, RGR, namun tidak berpengaruh pada SR udang vaname. Enzim papain sebesar $0,1 \% / \mathrm{kg}$ pakan merupakan dosis optimal pada EPP, PER dan RGR menghasilkan nilai maksimal sebesar $66,51 \%$, 1,64 dan $4,22 \% /$ hari.
\end{abstract}

Kata kunci: Litopenaeus vannamei, enzim papain, pakan, protein

\section{Supplementation of Papain in Feed on Growth Performance, Efficiency of Feed Utilization, and Survival Rate of Whiteleg Shrimp (Litopenaeus vannamei)}

ABSTRACT: White shrimp (Litopenaeus vannamei) is a carnivorous animal that difficult to digests vegetable protein in the feed so that the efficiency of feed utilization is not maximal. Nearly $40-60 \%$ of the total production cost is only for feed cost. Feed efficiency is improved by using papain in the feed which can increase the breakdown and consumption of feed containing vegetable protein so that it can easily increase the digestibility of feed protein. This study examines the effect of papain supplementation in feed on the growth performance, efficiency of feed utilization, and survival rate of white shrimps. The test animals were white shrimp with an average weight of $3.02 \pm 0.21 \mathrm{~g} /$ individuals obtained from the whiteleg shrimp farmers in Blebak Village, Mlonggo District, Jepara. The method in this study was an experimental method, with a completely randomized design, 4 treatments, and 3 repetitions. There were 4 supplements of papain in feed: $A(0 \%), B(0.1 \%), C$ $(0.2 \%)$, and $D(0.3 \%)$. The parameters were EPP, PER, RGR, SR, and water quality parameters. The results showed that the supplementation of the papain in feed increased the EPP, PER, RGR, but had no effect on the SR of white shrimp. Papain of $0.1 \% / \mathrm{kg}$ of feed was the optimal dose at $E P P, P E R$, and RGR resulting in a maximum value of $66.51 \%, 1.64$ and $4.22 \%$ / day.

Keywords: Litopenaeus vannamei, papain, feed, protein 


\section{PENDAHULUAN}

Udang vaname (Litopenaeus vannamei) merupakan komoditas unggulan nasional yang memiliki nilai ekonomis tinggi dilihat dari produksi udang vaname tahun 2017 mencapai 555.183 ton (KKP, 2018). Udang tersebut memiliki keunggulan untuk kegiatan budidaya dalam tambak intensif karena memiliki toleransi terhadap berbagai macam salinitas dan penyakit, memiliki pertumbuhan cepat, dan mampu bertahan dalam kepadatan tinggi (Khanjani et al., 2016). Jika dibandingkan dengan udang windu, udang vaname memiliki keunggulan yaitu dapat dipelihara dengan kisaran salinitas yang lebar (0,5-45 ppt), dapat ditebar dengan kepadatan yang tinggi hingga lebih dari 150 ekor $/ \mathrm{m}^{2}$, serta lebih resisten terhadap kualitas lingkungan yang rendah (Fendjalang et al., 2016).

Peningkatan produksi udang vaname berbanding lurus dengan kebutuhan pakan. Masalah yang sering dihadapi pembudidaya udang vaname adalah efisiensi pemanfaatan pakan yang belum maksimal sehingga hampir $40-60 \%$ dari total biaya produksi hanya untuk pakan (Olmos et al., 2011). Hal ini disebabkan udang vaname sukar mencerna protein nabati dikarenakan merupakan hewan karnivora (Mo et al., 2016). Efisiensi pemanfaatan pakan udang dapat ditingkatkan dengan penambahan enzim papain (Patil dan Singh, 2014), yang mampu memecah protein menjadi asam amino sehingga lebih mudah dicerna (Amri dan Mamboya, 2012) dan dapat meningkatkan penguraian dan pencernaan bahan pakan yang mengandung protein nabati (Mo et al., 2016).

Enzim papain adalah enzim proteolitik dari family sistein proteinase. Enzim ini berasal dari daun pepaya (Carica papaya $L$ ), buah mentah dan getah pepaya dan getah yang keluar dari pepaya hijau. Daun pepaya mengandung sekitar $9 \%$ protein dan 5,3\% papain dan juga mengandung vitamin C (286 mg/100 g) dan vitamin E (30 mg/100 mg). Pepaya adalah salah satu sumber herbal dari enzim proteolitik. Bahan aktif utama pohon pepaya adalah papain yang merupakan enzim protein (Singh et al., 2011).

Penambahan enzim papain dalam pakan terbukti dapat meningkatkan efisiensi pemanfaatan pakan, kecernaan nutrisi dan pertumbuhan ikan seperti yang dilaporkan oleh Patil dan Singh (2014) menyatakan penambahan enzim papain $0,1 \%$ dalam pakan buatan memberikan efisiensi pakan dan pertumbuhan terbaik pada udang galah (Macrobrachium rosenbergii), Muchlisin et al. (2016) mengemukakan penambahan papain $27,5 \mathrm{mg} / \mathrm{kg}$ pakan merupakan dosis terbaik bagi pertumbuhan ikan keureling (Tor Tambra) dengan ukuran 0,30 g dan 3,5 cm, Khati et al. (2015) menjelaskan bahwa penambahan sebesar $10 \mathrm{~g} / \mathrm{kg}$ pakan papain memberikan pertumbuhan dan protein efisiensi ratio terbaik pada ikan fingerling Labeo rohita, Rachmawati et al. (2018) menyebutkan bahwa penambahan enzim papain sebesar $0,24-0,31 \%$ merupakan kisaran dosis optimum untuk efisiensi pemanfaatan pakan dan pertumbuhan lobster air tawar (Cherax quadricarinatus), Rachmawati et al. (2019) meyatakan bahwa dosis enzim papain sebesar 1.67 to $1.89 \% / \mathrm{kg}$ pakan merupakan kisaran dosis optimal untuk efisiensi pemanfaatan pakan, rasio protein efisiensi dan pertumbuhan benih lele Sangkuriang (Clarias gariepinus), Rachmawati dan Prihanto, (2019) mengemukakan enzim papain dosis $4 \mathrm{~g} / \mathrm{kg}$ pakan merupakan dosis terbaik kecernaan nutrisi, efisiensi pemanfaatan pakan dan pertumbuhan ikan patin (Pangasius hypopthalmus). Sejauh ini masih sedikit informasi penelitian pemberian enzim papain dalam pakan udang vaname, oleh karena itu pentingya penelitian ini dilakukan. Tujuan penelitian ini adalah mengkaji pengaruh suplementasi enzim papain dalam pakan terhadap efisiensi pemanfaatan pakan, performa pertumbuhan dan kelulushidupan udang vaname.

\section{MATERI DAN METODE}

Penelitian ini dilaksanakan di Laboratorium Pakan Buatan Balai Besar Perikanan Budidaya Air Payau (BBPBAP), Jepara pada bulan Agustus s/d November 2019. Hewan uji yang digunakan adalah udang vaname dengan bobot rata-rata 3,02 $\pm 0,21 \mathrm{~g} /$ ekor yang diperoleh dari pembudidaya udang vaname Desa Blebak, Kecamatan Mlonggo, Jepara. Adaptasi udang vaname terhadap pakan dan lingkungan dilaksanakan selama satu minggu sebelum penelitian. Pakan buatan komersial tanpa penambahan enzim papain diberikan selama proses adaptasi dan pemberian padan secara ad satiation (udang sampai kenyang). Udang dipuasakan selama satu hari sebelum pelaksanaan penelitian untuk menghilangkan sisa metabolisme dalam tubuh udang. Udang vaname yang digunakan sebagai hewan uji dipilih yang berukuran seragam, aktif berenang, sehat, dan tidak cacat 
(Rachmawati et al., 2017).

Metode penelitian yang digunakan adalah rancangan acak lengkap (RAL), 4 perlakuan dan 3 kali pengulangan. Perlakuan dalam penelitian ini adalah suplementasi enzim papain dalam pakan dengan dosis berbeda. Pakan uji yang digunakan dalam penelitian adalah pakan komersil berbentuk pellet dengan kandungan protein 37\% yang disuplementasi dengan enzim papain sesuai perlakuan yaitu $\mathrm{A}(0 \% / \mathrm{kg}$ pakan), $\mathrm{B}(0,1 \% / \mathrm{kg}$ pakan), $\mathrm{C}(0,2 \% / \mathrm{kg}$ pakan), dan $\mathrm{D}(0,3 \% / \mathrm{kg}$ pakan). Penentuan dosis dalam penelitian ini memodifikasi hasil penelitian Patil dan Singh (2014) yang menyatakan bahwa $0,1 \% / \mathrm{kg}$ pakan merupakan dosis enzim papain terbaik untuk pertumbuhan udang galah (Macrobrachium rosenbergii). Enzim papain yang digunakan dalam penelitian ini adalah enzim papain yang diproduksi oleh Balai Besar Perikanan Air Payau, Jepara. Suplementasi enzim papain dalam pakan dengan cara menyemprotkan enzim ke dalam pakan sesuai dengan metode Merrifield et al. (2011). Pemberian pakan selama penelitian menggunakan metode fix feeding rate sebanyak $5 \% /$ bobot biomassa/hari dan frekuensi pakan yang diberikan sebanyak 4 kali sehari pada pukul 08.00, 14.00,18.00, 21.00 selama 42 hari. Hasil analisis proksimat pakan uji setelah suplementasi enzim papain dapat dilihat pada Tabel 1.

Wadah pemeliharan yang digunakan dalam penelitian ini adalah kontener plastik kapasitas $25 \mathrm{~L}$ air sebanyak 12 buah dan masing-masing dilengkapi dengan sistem aerasi menggunakan blower dengan daya 100-watt agar kebutuhan oksigen udang vaname terpenuhi. Padat penebaran udang vaname sebesar 1 ekor/L (Dahlan et al., 2017). Parameter kualitas air yang diamati meliputi suhu, salinitas, DO, dan amoniak. Pemeliharaan kualitas air dilakukan dengan cara penyiponan feses dan sisa pakan 2 kali dalam satu hari yaitu pada pagi hari dan sore hari.

Parameter yang diamati selama penelitian meliputi total konsumsi pakan (TKP), efisiensi pemanfaatan pakan (EPP), rasio efisiensi protein (PER), laju pertumbuhan relatif (RGR) yang menggunakan perhitungan menurut NRC (2011), kelulushidupan (SR) yang menggunakan perhitungan menurut Effendie (1997), dan parameter kualitas air.

Data parameter yang telah diperoleh TKP, EPP, PER, RGR, dan SR dianalisis menggunakan analisis ragam (ANOVA) pada taraf kepercayaan 95\% dan $99 \%$ untuk melihat pengaruh perlakuan. Apabila dalam analisis ragam diperoleh berpengaruh nyata $(P<0,05)$ atau berpengaruh sangat nyata $(\mathrm{P}<0,01)$, maka dilakukan uji wilayah ganda duncan untuk mengetahui perbedaan antar perlakuan. Dosis enzim papain optimal pada pakan dilakukan analisis polinomial ortogonal dengan software Maple 2016 (Stell et al., 1997).

Tabel 1. Analisis proksimat kandungan nutrisi pakan setelah diberikan enzim papain bahan kering

\begin{tabular}{|c|c|c|c|c|c|}
\hline \multirow{2}{*}{ Pakan Perlakuan } & \multicolumn{4}{|c|}{ Komponen (\%) } & \multirow{2}{*}{$\begin{array}{l}\text { Total } \\
\text { (\%) }\end{array}$} \\
\hline & Protein* & BETN $^{*}$ & Lemak * & $\mathrm{Abu}^{*}$ & \\
\hline$A$ & 40,21 & 38,65 & 1,31 & 10,33 & 100 \\
\hline B & 40,71 & 38,88 & 0,83 & 10,28 & 100 \\
\hline C & 40,99 & 37,54 & 0,70 & 10,11 & 100 \\
\hline D & 41,80 & 39,43 & 0,60 & 10,15 & 100 \\
\hline
\end{tabular}

*Sumber: Laboratorium IImu Nutrisi dan Pakan, Fakultas Peternakan dan Pertanian, Universitas Diponegoro, Semarang (2019)

\section{HASIL DAN PEMBAHASAN}

Data total konsumsi pakan (TKP), efisiensi pemanfaatan pakan (EPP), rasio efisiensi protein (PER), laju pertumbuhan relatif (RGR), kelulushidupan (SR) dan parameter kualitas air udang vaname selama penelitian disajikan pada Tabel 2 dan 3. Hasil pengukuran parameter kualitas air pada media pemeliharaan udang vaname $L$. vannamei selama penelitian menunjukkan bahwa kualitas air masih berada dalam kisaran pustaka yang disarankan sehingga layak untuk budidaya udang vaname.

Hasil analisis ragam menunjukan bahwa pemberian pakan dengan suplementasi enzim papain dalam pakan tidak berpengaruh nyata $(\mathrm{P}<0,05)$ terhadap TKP udang vaname. Obirikorang et al. (2015) mengemukakan bahwa tinggi rendahnya total konsumsi pakan dipengaruhi oleh kandungan nutrisi pada pakan. Hasil penelitian ini menunjukkan karena kandungan nutrisi pada pakan dalam penelitian ini tidak terdapat perbedaan yang signifikan antar perlakuan (Tabel 1). 
Efisiensi pemanfaatan pakan yang tinggi menunjukkan bahwa pakan yang diberikan dimanfaatkan secara baik untuk menghasilkan pertumbuhan (NRC, 2011). Hasil analisis ragam menunjukan bahwa suplementasi enzim papain dalam pakan berpengaruh sangat nyata $(P<0,01)$ terhadap EPP udang vaname. Berdasarkan hasil penelitian menunjukkan bahwa nilai EPP tertinggi terdapat pada perlakuan $B$ dengan penambahan enzim papain $0,1 \%$ pakan yakni sebesar $66,51 \%$. Hal ini diduga dosis enzim papain sebesar $0,1 \%$ merupakan dosis maksimal untuk menghidrolisis rantai polipeptida menjadi asam amino sehingga pakan lebih mudah dicerna dan diserap udang vaname. Semakin banyak nutrisi dalam pakan yang terhidrolisis dan mudah terserap maka akan semakin tinggi nilai efisiensi pemanfaatan pakan udang vaneme. Hal ini diperkuat oleh Singh et al. (2011) dan Rachmawati et al. (2018) yang menyatakan bahwa papain adalah enzim protease yang menghidrolisis protein menjadi peptida dan merupakan faktor kunci untuk menambah pencernaan protein, penyerapan yang cepat dan membantu meningkatkan efisiensi pemanfaatan pakan.

Nilai efisiensi pemanfaatan terendah dalam penelitian ini terdapat pada perlakuan A $(0 \% / \mathrm{kg}$ pakan) sebesar $47,09 \%$. Hal ini diduga karena protein dalam pakan tidak tercerna dengan baik sehingga penyerapan nutrisi tidak maksimal. Hasil penelitian ini menunjukkan bahwa udang vaname yang diberi pakan dengan suplementasi enzim papain memiliki nilai EPP lebih tinggi dari tanpa suplementasi, yaitu perlakuan B $(0,1 \% / \mathrm{kg}$ pakan) sebesar $66,51 \%, \mathrm{C}(0,2 \% / \mathrm{kg}$ pakan), sebesar $61,82 \%$, D (0,3\%/kg pakan) sebesar $60,61 \%$ dan A (0\%/.kg pakan) sebesar $47,09 \%$. Hal ini menunjukkan bahwa penambahan enzim papain dapat meningkatkan daya cerna pakan dan selanjuntya mempengaruhi efisiensi pemanfaatan pakan. Enzim papain merupakan enzim proteolitik memainkan peranan penting dalam proses pencernaan protein sehingga bisa diserap oleh tubuh ikan (Rachmawati dan Prihanto, 2019). Peningkatan daya cerna pakan yang mengandung enzim papain dikarenakan sudah tersedianya enzim proteolitik dalam pakan yang mampu membantu proses hidrolisis protein dalam pencernaan ikan (Patil dan Singh, 2014). Nilai EPP udang vaname yang diberi pakan dengan suplementasi enzim papain dinyatakan cukup baik karena memiliki nilai diatas $50 \%$. Hal ini sesuai dengan pernyataan Craig dan Helfrich (2002) bahwa pakan dapat dikatakan baik bila nilai efisiensi pakan lebih dari 50\% atau bahkan mendekati 100\%. Hasil penelitian serupa dilaporkan oleh Muchlisin et al. (2016), Rostika et al. (2018), Rachmawati et al. (2018) dan Rachmawati et al. (2019).

Tabel 2. Nilai TKP, EPP, PER, RGR, dan SR udang vaname (L. vannameI) selama penelitian

\begin{tabular}{lccccc}
\hline \multirow{2}{*}{ Perlakuan } & \multicolumn{5}{c}{ Variabel yang Diamati } \\
\cline { 2 - 6 } & TKP $(\mathrm{g})$ & EPP $(\%)$ & PER $(\%)$ & RGR $(\% /$ hari $)$ & SR $(\%)$ \\
\hline A & $153,50 \pm 5,61^{\mathrm{a}}$ & $47,09 \pm 4,87^{\mathrm{b}}$ & $1,17 \pm 0,12^{\mathrm{c}}$ & $2,83 \pm 0,37^{\mathrm{b}}$ & $86,67 \pm 7,64^{\mathrm{a}}$ \\
$\mathrm{B}$ & $161,21 \pm 6,69^{\mathrm{a}}$ & $66,51 \pm 3,62^{\mathrm{a}}$ & $1,64 \pm 0,09^{\mathrm{a}}$ & $4,22 \pm 0,48^{\mathrm{a}}$ & $90,00 \pm 5,00^{\mathrm{a}}$ \\
$\mathrm{C}$ & $161,62 \pm 9,30^{\mathrm{a}}$ & $61,82 \pm 3,04^{\mathrm{a}}$ & $1,51 \pm 0,07^{\mathrm{b}}$ & $3,97 \pm 0,19^{\mathrm{a}}$ & $91,67 \pm 5,77^{\mathrm{a}}$ \\
$\mathrm{D}$ & $160,14 \pm 3,15^{\mathrm{a}}$ & $60,61 \pm 1,38^{\mathrm{a}}$ & $1,44 \pm 0,03^{\mathrm{b}}$ & $3,79 \pm 0,14^{\mathrm{a}}$ & $88,33 \pm 2,89^{\mathrm{a}}$ \\
\hline
\end{tabular}

Keterangan: Nilai dengan supercript yang sama pada kolom yang sama menunjukkan tidak adanya perbedaan yang nyata

Tabel 3. Hasil pengukuan parameter kualitas air pada media pemeliharaan udang vaname $(L$. vannameI) selama penelitian

\begin{tabular}{cccccc}
\hline \multirow{2}{*}{ Perlakuan } & \multicolumn{5}{c}{ Kisaran Nilai Parameter Kualitas Air } \\
\cline { 2 - 6 } & Suhu $\left({ }^{\circ} \mathrm{C}\right)$ & $\mathrm{pH}$ & $\mathrm{DO}(\mathrm{mg} / \mathrm{L})$ & Salinitas $(\mathrm{ppt})$ & $\mathrm{NH}_{3}(\mathrm{mg} / \mathrm{L})$ \\
\hline $\mathrm{A}$ & $25,0-29,2$ & $6,5-7,2$ & $3,2-5,1$ & $22-25$ & $0,0040-0,0146$ \\
$\mathrm{~B}$ & $25,0-29,5$ & $6,5-7,3$ & $3,1-5,2$ & $22-25$ & $0,0042-0,0211$ \\
$\mathrm{C}$ & $25,1-29,6$ & $6,5-7,2$ & $3,1-4,8$ & $22-25$ & $0,0038-0,0151$ \\
D & $25,0-29,6$ & $6,5-7,2$ & $3,1-4,7$ & $22-25$ & $0,0041-0,0199$ \\
Pustaka & $25-30^{\mathrm{a}}$ & $6-9^{\mathrm{b}}$ & $3-20^{\mathrm{c}}$ & $5-35^{\mathrm{a}}$ & $0-1,22^{\mathrm{c}}$ \\
\hline
\end{tabular}

Keterangan: a) Fast dan Lester (1992); b) Boyd (2003); c) Wyban dan Sweeney (1991) 
Hasil penelitian ini juga menunjukkan bahwa peningkatan dosis enzim papain belum tentu memberikan hasil EPP yang tinggi dikarenakan enzim memiliki kadar optimum. Kondisi tersebut berkaitan dengan mekanisme kerja dari enzim. Khattak et al. (2006) menjelaskan bahwa enzim mengkatalis secara spesifik dan bertindak pada satu substrat. Pernyataan tersebut menyimpulkan bahwa ketika tidak tersedia substrat untuk enzim, maka tidak ada aktivitas enzim. Hal ini terjadi pada perlakuan yang penambahan enzimnya berlebihan namun substratnya terbatas. Penambahan enzim secara berlebihan dengan substrat terbatas tidak dapat meningkatkan aktivitas enzim, karena aktivitas enzim terhenti saat substrat habis. Adugna et al. (2004) juga melaporkan bahwa meningkatkan konsentrasi subtrat dapat meningkatkan aktivitas enzim sampai batas maksimum tercapai. Kondisi tersebut menunjukkan bahwa molekul substrat dan molekul enzim akan bergabung pada sisi aktif sampai semua sisi aktif terpakai, pada keadaan tersebut enzim dikatakan dalam keadaan maksimum. Hasil uji Polinomial Orthogonal hubungan antara suplementasi enzim papain dalam pakan dengan EPP memiliki pola kuadratik dengan persamaan $Y=-526,84 x^{2}+192,55 x+48,452, R^{2}=0,713$

(Gambar 1). Dosis enzim papain optimal yang didapat dari persamaan tersebut sebesar $0,1 \%$ dan menghasilkan EPP maksimal 66,51\%.

Protein efisiensi rasio merupakan ukuran yang digunakan untuk menunjukkan seberapa baik sumber protein dalam pakan dapat memenuhi kebutuhan asam amino essensial pada ikan (Singh et al., 2011). Tabel 2 menunjukkan bahwa suplementasi enzim papain dalam pakan ikan terbukti dapat meningkatkan rasio efisiensi protein udang vaname, dimana udang vaname yang diberi pakan dengan suplementasi enzim papain dosis $0,1 \% / \mathrm{kg}$ pakan (B), 0,2\%/kg pakan (C) dan $0,3 \% / \mathrm{kg}$ pakan (D) memiliki nilai PER lebih tinggi dari tanpa suplementasi $0 \% / \mathrm{kg}$ pakan (A). Nilai rasio efisiensi protein tertinggi dalam penelitian ini terdapat pada perlakuan B $(0,1 \% / \mathrm{kg}$ pakan) sebesar $1,64 \%$. Hal itu diduga karena karena perlakuan B mengandung dosis enzim papain yang tepat untuk proses pemecahan protein pakan yang akan meningkatkan nilai PER udang vaname. Rachmawati et al. (2018) melaporkan penambahan enzim papain dalam pakan dapat meningkatkan daya cerna protein yang lebih tinggi jika dibandingkan dengan pakan tanpa penambahan enzim papain. Menurut Khati et al. (2015), enzim papain adalah enzim protease yang menghidrolisis protein, yang merupakan faktor kunci untuk meningkatkan daya cerna protein dan penyerapannya, yang pada akhirnya mempengaruhi pertumbuhan. Enzim papain bertindak sebagai katalis biologis yang dapat meningkatkan daya cerna pakan kualitas rendah, sehingga biaya pakan dapat ditekan. Enzim papain dapat mengurangi faktor negatif dari asam fitat yang berasal dari bahan dasar nabati pakan. Hasil penelitian serupa pada Labio rohita (Khati et al., 2015), Cyprinus carpio (Singh et al., 2011), M. rosenbergii (Patil dan Singh, 2014), Clarias gariepinus (Rachmawati et al., 2019), P. hypopthalmus (Rachmawati dan Prihanto, 2019). Hasil uji Polinomial Orthogonal hubungan antara suplementasi enzim papain dalam pakan dengan PER memiliki pola kuadratik dengan persamaan $Y=-13,558 x 2+4,7399 x+1,2038, R^{2}=0,691$ (Gambar 2). Dosis enzim papain optimal yang didapat dari persamaan tersebut sebesar $0,1 \%$ mampu menghasilkan PER maksimal 1,64\%.

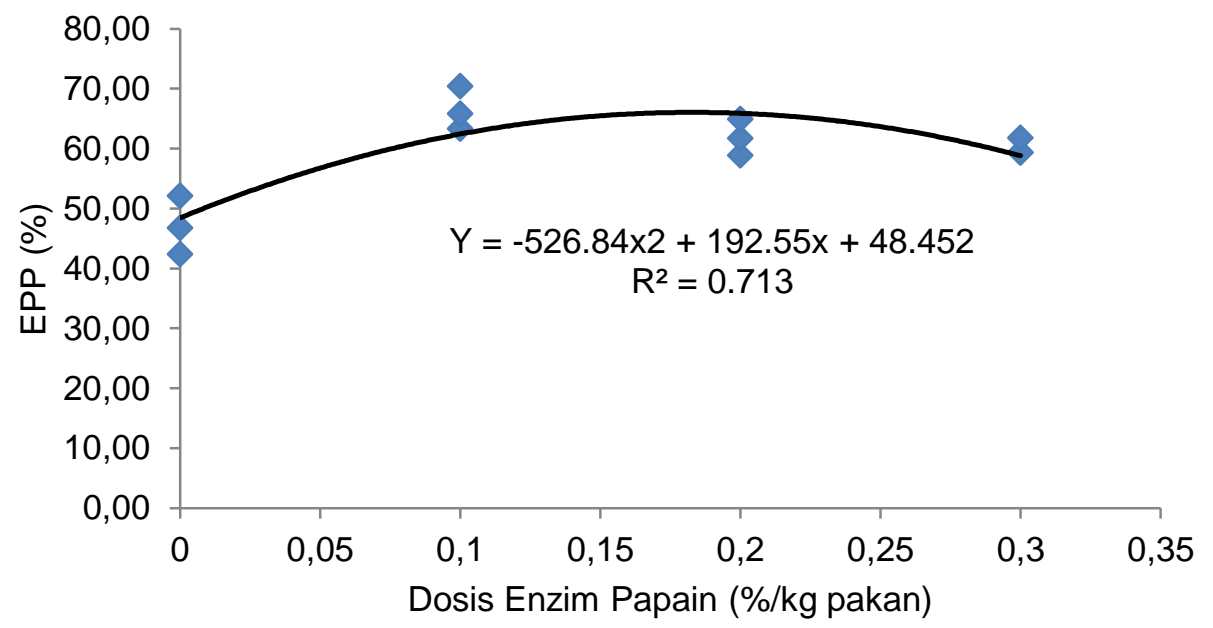

Gambar 1. Grafik polinomial orthogonal hubungan antara suplementasi enzim papain dalam pakan dengan EPP udang vaname selama penelitian 
Hasil analisis ragam menunjukkan bahwa suplementasi enzim papain dalam pakan berpengaruh sangat nyata $(P<0,01)$ terhadap RGR udang vaname. Nilai RGR tertinggi pada perlakuan $B(0,1 \% / \mathrm{kg}$ pakan) sebesar $4,22 \% /$ hari, diikuti $C(0,2 \% / \mathrm{kg}$ paka) sebesar $3,97 \% /$ hari, $\mathrm{D}(0,3 \% / \mathrm{kg}$ pakan) sebesar $3,79 \% /$ hari dan $\mathrm{A}(0 \% / \mathrm{kg}$ pakan) sebesar $2,83 \% /$ hari. Tingginya nilai RGR pada udang vaname yang diberi pakan $\mathrm{B}(0,1 \% / \mathrm{kg}$ pakan) diduga pada dosis tersebut merupakan dosis yang sesuai bagi enzim papain untuk bekerja maksimal menghidrolis protein nabati menjadi asam amino sehingga meningkatkan efisiensi pemanfaatan pakan dan meningkatkan RGR udang vaname. Dawood et al. (2014) menyatakan enzim papain meningkatkan nilai nutrisi pakan terutama yang berbahan dasar protein nabati. Hasil penelitian (Tabel 2) menunjukkan udang vaname yang diberi pakan $B(0,1 \% / \mathrm{kg}$ papan) memiliki nilai EPP tertinggi, sehingga dapat disimpulkan bhwa nilai RGR berbanding lurus dengan nilai EPP. Semakin tinggi nilai EPP maka semakin tinggi pula nilai RGR. Rachmawati et al. (2018) menyatakan nilai EPP yang tinggi berkaitan dengan laju pertumbuhan yang tinggi. Nilai EPP yang tinggi menunjukkan bahwa sedikit nutrisi pakan yang dirombak untuk memenuhi kebutuhan energi dan selebihnya untuk pertumbuhan. Hal serupa juga terjadi pada penelitian Singh et al. (2011), Patil dan Singh, (2014), Muchlisin et al. (2016), Muchlisin et al. (2016), Mo et al. (2016), Rachmawati et al., 2019), Rachmawati dan Prihanto, (2019). Hasil uji Polinomial Orthogonal hubungan antara suplementasi enzim papain dalam pakan dengan RGR memiliki pola kuadratik dengan persamaan $Y=$ $-39,5 \times 2+14,483 x+2,9133$ (Gambar 3 ), $R^{2}=0,695$. Dosis enzim papain optimal yang didapat dari persamaan tersebut sebesar 0,1\% mampu menghasilkan RGR maksimal 4,22\%/hari.

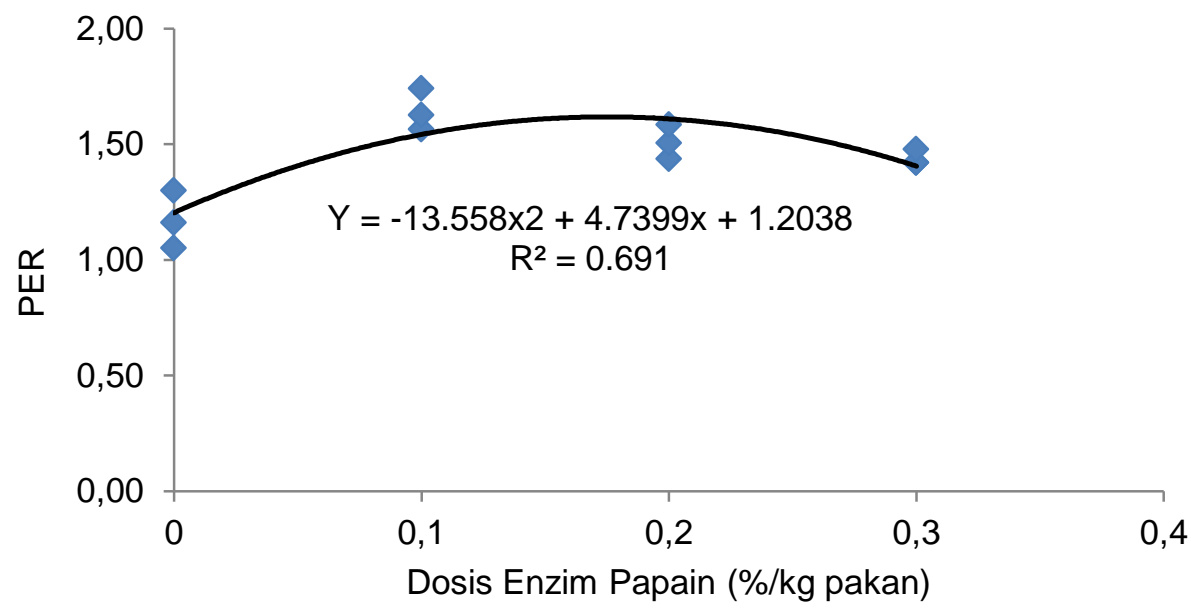

Gambar 2. Grafik polinomial orthogonal hubungan antara suplementasi enzim papain dalam pakan dengan PER udang vaname selama penelitian

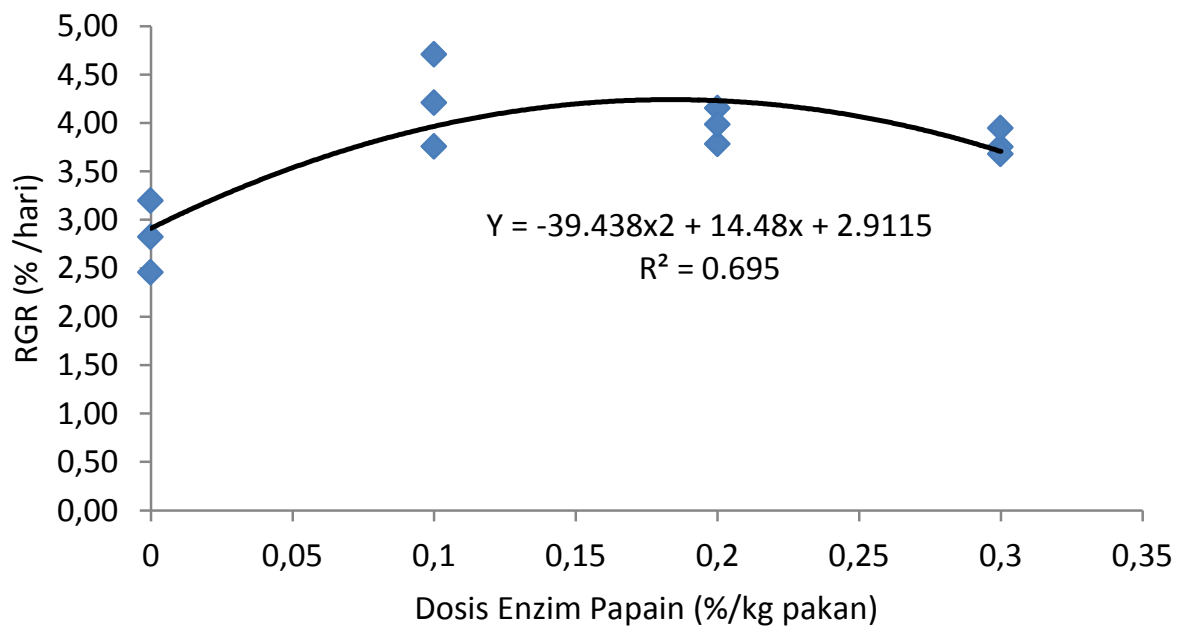

Gambar 3. Grafik polinomial orthogonal hubungan antara suplementasi enzim papain dalam pakan dengan RGR udang vaname selama penelitian 
Kelulushidupan merupakan suatu nilai perbandingan antara jumlah organisme awal saat penebaran yang dinyatakan dalam bentuk persen dimana semakin besar nilai persentase menunjukkan semakin banyak organisme yang hidup selama pemeliharaan (Effendi, 1997). Hasil analisis ragam menunjukkan bahwa suplrmrntasi enzim papain dalam pakan tidak berpengaruh nyata $(P>0,05)$ terhadap SR udang vaname. Hal ini menunjukkan bahwa suplementasi enzim papain yang merupakan enzim proteolitik dalam pakan tidak berpengaruh terhadap kelulushidupan udang vaname. Dabrowski dan Glogowski (1977) mengemukakan enzim proteolitik jika ditambahkan ke dalam pakan itu tidak berpengaruh signifikan pada tingkat kelulushidupan ikan. Kematian udang vanname selama penelitian diduga karena adanya sifat kanibalisme dan aktivitas molting. Hasil penelitian serupa dilaporkan oleh Patil dan Singh (2014), Khati et al. (2015), Singh et al. (2011), Mo et al. (2016), Rachmawati et al. (2018), Rachmawati et al. (2018), Rachmawati dan Prihanto, (2019).

\section{KESIMPULAN}

Suplementasi enzim papain dalam pakan dapat meningkatkan efisiensi pemanfaatan pakan dan performan pertumbuhan udang vaname, namun tidak berpengaruh terhadap kelulushidupan udang vaname. Dosis enzim papain sebesar $0,1 \% / \mathrm{kg}$ pakan merupakan dosis optimal bagi udang vaname yang menghasilkan nilai maksimal EPP sebesar $66,51 \%$ dan RGR sebesar $4,22 \%$ /hari.

\section{DAFTAR PUSTAKA}

Adugna, S., Alemu, L.A.M., Kelemu, T., Tekola, H., Kibret, B. \& Genet, S. 2004. Medical Biochemistry. Gondar University; Jimma University and Debub University, In collaboration with the Ethiopia Public Health Training Initiative; The Carter Center; The Ethiopia Ministry of Health, and The Ethiopia Ministry of Education, $264 \mathrm{p}$.

Amri, E. \& Mamboya, F. 2012. Papain, a Plant Enzyme of Biological Importance: A Review. American Journal of Biochemistry and Biotechnology, 8(2):99-104. DOI: 10.3844/ ajbbsp.2012.99.104.

Boyd C.E. 2003. Guidelines for aquaculture effluent management at the farm-level. Aquaculture, 226(1-4):101-112. DOI: https://doi.org/10.1016/S0044-8486(03)00471-X.

Craig. S \& Helfrich, L.A. 2002. Understanding Fish Nutrition, Feeds and Feeding. Cooperative Extension Service Publication. Virginia State University, USA.

Dabrowski, K. \& Glogowski, K. 1977. A study of application of proteolytic enzymes to fish food. Aquaculture, 12: 249-360. DOI: 10.1016/0044-8486(77)90213-7.

Dawood, M.A.O., Dakar, A.E., Mohsen, M., Abdelraouf, E., Koshio, S., Ishikawa, M. \& Yokoyama, S. 2014. Effects of Using Exogenous Digestive Enzymes or Natural Enhancer Mixture on Growth, Feed Utilization, and Body Composition of Rabbitfish, Siganus rivulatus. Journal of Agricultural Science and Technology, 8(4):180-187.

Dahlan, J., Hamzah, M. \& Kurnia, A. 2017. Pertumbuhan Udang Vaname (Litopenaeus vannamei) Yang Dikultur Pada Sistem Bioflok dengan Penambahan Probiotik. Jurnal Sains dan Inovasi Perikanan. 1(1):19-27

Effendie, M.I. 1997. Biologi Perikanan. Yayasan Pustaka Nusantara, Yogyakarta, $163 \mathrm{hlm}$.

Fast, A.W. \& Lester, L.J., 1992. Marine Shrimp Culture: Principles and Practices Development in Aquaculture and Fisheries Sciences. Fast, A. W. \& Lester, L. J. (eds.), Volume 23 ed., Amsterdam: Elsevier, 862 p., ISBN: 9781483291048.

Fendjalang, S., Budiardi, T., Supriyono, E. \& Effendi, I. 2016. Produksi Udang Vaname (Litopenaeus Vannamei) pada Karamba Jaring Apung Dengan Padat Tebar Berbeda di Selat Kepulauan Seribu. Jurnal IImu Dan Teknologi Kelautan Tropis, 8(1): 201-214.

Kementerian Kelautan Perikanan. 2018. Budidaya udang masih sangat potensial. Http://kkp.go.id/artikel/budidaya udang masih sangat potensial. Diakses tanggal 27 Mei 2020.

Khanjani M.H., Sajjadi, M.M., Alizadeh \& Sourinejad, I. 2016. Study on nursery growth performance of Pacific white shrimp (Litopenaeus vannamei Boone, 1931) under different feeding levels in zero water exchange system. Iranian Journal of Fisheries Sciences 15(4): 1465-1484. 
Khattak, F.M., Pasha, T.N., Hayat, Z. \& Mahmud, A. 2006. Enzymes in Poultry Nutrition. Journal of Animal and Plant Sciences, 16:1-2.

Khati, A., Danish, M., Mehta, K.S. \& Pandey, N. 2015. Estimation of Growth Parameters in Fingerlings of Labeo rohita (Hamilton, 1822) Fed with Exogenous Nutrizyme in Tarai Region of Uttarakhand, India. African Journal of Agricultural Research. 10(30):3000-3007. DOI: 10.5897/AJAR2015.9729

Merrifield D.L., Bradley G., Harper G.M., Baker R.T.M., Munn C.B., \& Davies S.J. 2011. Assessment of the effects of vegetative and lyophilized Pediococcus acidilactici on growth, feed utilization, intestinal colonization and health parameters of rainbow trout (Oncorhynchus mykiss Walbaum). Aqua. Nutrition, 17(1):73-79. DOI: 10.1111/j.1365-2095.2009. 00712.x

Mo, W.Y., Lau, R.S.S., Kwok, A.C.K. \& Wong, M.H. 2016. Use of Soybean Meal and Papain to Partially Replace Animal Protein for Culturing Three Marine Fish Species: Fish Growth and Water Quality. Environmental Pollution, 219:815-820. DOI: 10.1016/j.envpol.2016.07.059.

Muchlisin, Z.A., Afrido, F., Murda, T., Fadli, N., Muhammadar, A.A., Jalil, Z. \& Yulvizar, C. 2016. The Effectiveness of Experimental Diet with Varying Levels of Papain on The Growth Performance, Survival Rate and Feed Utilization of Keureling Fish (Tor tambra). Biosaintifika: Journal of Biology \& Biology Education, 8(2):172-177.

NRC (National Research Council). 2011. Proteins and Amino Acids. Nutrient Requirements of Fish and Shrimp. National Academy Press, Washington, D.C., pp. 57-101.

Obikiorang, K.A., Amisaha, S., Fialor, S.C. \& Skov, P.V. 2015. Effects of Dietary Inclusions of Oilseed Meals on Physical Characteristics and Feed Intake of Diets for the Nile Tilapia, Oreochromis niloticus. Aquaculture Reports, 1:43-49. DOI: 10.1016/j.aqrep.2015.01.002.

Olmos, J., Ochoa, L., Michel, J.P. \& Contreras, R. 2011. Functional Feed Assessment on Litopenaeus vannamei Using 100\% Fish Meal Replacement by Soybean Meal, High Levels of Complex Carbohydrates and Bacillus Probiotic Strains. Journal Marine Drugs, (9):1119-1132. DOI: $10.3390 / m d 9061119$.

Patil, D.W., \& Singh, H. 2014. Effect of Papain Supplemented Diet on Growth and Survival of PostLarvae of Macrobrachium rosenbergii. International Journal of Fisheries and Aquatic Studies, 1(6):176-179.

Rachmawati, D., Istiyanto, S., \& Maizirwan, M. 2017. Effect of phytase on growth performance, diet utilization efficiency and nutrient digestibility in fingerlings of Chanos chanos (Forsskal 1775). Philippine Journal of Science, 146(3):237-245.

Rachmawati, D., Prihanto, A.A., Setyobudi, R.H., \& Anne, O. 2018. Effect of Papain Enzyme in Feed on Digestibility of Feed, Growth Performance, and Survival Rate in Post Larvae of Freshwater Lobster [Cherax quadricarinatus (Von Martens, 1868)]. Proceedings of the Pakistan Academy of Sciences: Pakistan Academy of Sciences B. Life and Environmental Sciences, 55(3):31-39.

Rachmawati, D., Hutabarat, J., Samidjan, I., \& Windarto, S. 2019. The effects of papain enzymeenriched diet on protease enzyme activities, feed efficiency, and growth of fingerlings of Sangkuriang catfish (Clarias gariepinus) reared in tarpaulin pool. AACL Bioflux, 12(6):21772187.

Rachmawati, D., \& Prihanto, A.A. 2019. Effect of papain enzyme supplementation on growth performance and nutrient utilization of catfish (Pangasius hypopthalmus). Malaysian Applied Biology Journal, 48(5):1-10.

Rostika. R., Sunarto, H.N. Sugiyanto, \& Dewanti, L.P. 2018. The effectiveness of crude papain enzyme supplement for tilapia's (Oreochromis niloticus) growth at the floating nets of Cirata Reservoir. IOP Conference Series: Earth and Environmental Science, 139.

Singh, P., S. Maqsood, M. H. Samoon, V. Phulia, M. Danish, and R. S. Chalal. 2011. Exogenoush Supplementation of Papain as Growth Promoter in Diet of Fingerlings of Cyprinus carpio. Faculty of Fisheries, Shere-e-Kashmir University of Agricultural Science and Technology of Kashmir, India. 3:1-9 pp.

Steel, R.G.D., Torrie J.H. \& Dickey, D.A.. 1997. Principles and Procedures of Statistics: A Biometrical Approach. 3rd Edition, McGraw Hill, Inc. Book Co., New York, pp:352-358.

Wyban, J.A. \& Sweeney, J.A. 1991. Intensive Shrimp Production Technology. The Oceanic Institute. Hawaii. USA. 